\title{
Bożena Kicińska
}

\section{THE INFLUENCE OF THE DIRECTION OF AIR INFLOW ON THE SULPHUR DIOXIDE CONCENTRATION IN POLAND}

The influence exerted by the meteorological conditions on the air pollution is often dealt with in the contemporary scientific literature. It is especially important to identify possibly well this relation in the case of areas, which feature the particularly disadvantageous aerosanitary conditions. This applies to a major part of Poland.

The paper reports on determination of the dependence of sulphur dioxide concentration in Poland on the direction of air inflow. This dependence was analysed on the basis of results of the daily measurements of $\mathrm{SO}_{2}$ concentrations in 54 stations (Fig. 1) belonging to the network of air pollution monitoring, carried out in the years 1993-97 (this network functioning under the supervision of the Institute of Environmental Protection), and the daily synoptic maps of the Institute of Meteorology and Water Management.

The years 1993-1997 were characterised in Poland by small changes in the total annual emissions of sulphur dioxide (between 2.7 and 2.4 million tons), with a slight downward tendency. A similar tendency was at that time observed in the majority of countries of Europe (OECD Environmental...). During this whole period locations of the main sources of $\mathrm{SO}_{2}$ emissions in Poland - primarily power generation and co-generation plants remained unchanged.

\section{THE SCOPE AND THE METHOD OF STUDY}

The strength of dependence of the sulphur dioxide concentration in Poland on the direction of the air inflow was determined with the use of the correlation methods. Statistical significance was evaluated using the Snedecor's $F$ statistic.

The main daily concentrations of sulphur dioxide in each station were calculated with distinction of the days with various directions of air inflow.

Probability of exceeding the definite threshold values of $\mathrm{SO}_{2}$ concentrations for different directions of air inflow (for these stations, where it is frequent that the legally admissible levels are exceeded) has been calculated. In order to describe the probability density distributions of the sulphur di- 


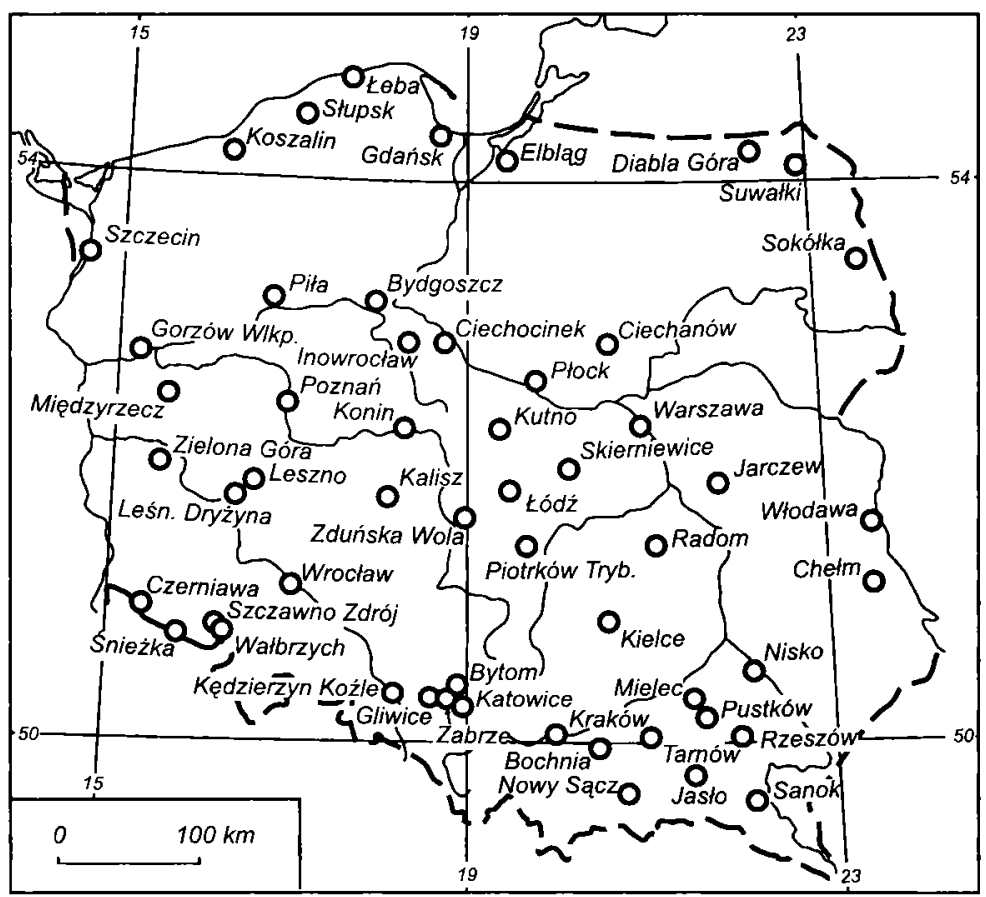

Fig. 1. Locations of the measurement stations.

oxide concentration the theoretical distribution functions were used: gamma, log-normal, and exponential. The choice of the optimum functions was performed by applying the $\chi^{2}$ test of consistence and the continuous Kolmogorov-Smirnov test.

The day-to-day variability of the concentration of sulphur dioxide in Poland for different directions of air inflow was determined.

In the final stage of work similarity of individual directions of air inflow in different regions of the country was assessed in terms of a set of features considered. For this purpose cluster analysis - an agglomeration algorithm based on Ward's hierarchical grouping - was applied. The similarity function used was based upon the Euclidean distance in the multidimensional space.

\section{ANNUAL CHANGES AND SPATIAL DIFFERENTIATION OF SULPHUR DIOXIDE CONCENTRATION IN POLAND}

A clear seasonal variation is well visible in the annual course of air pollution with sulphur dioxide in Poland. Higher concentration values are observed in the cold half-year, especially during winter, while lower values of concentration occur during the warm half-year, especially summer (Table 1, Fig. 2). This sharply appearing annual cycle is first of all due to seasonal 

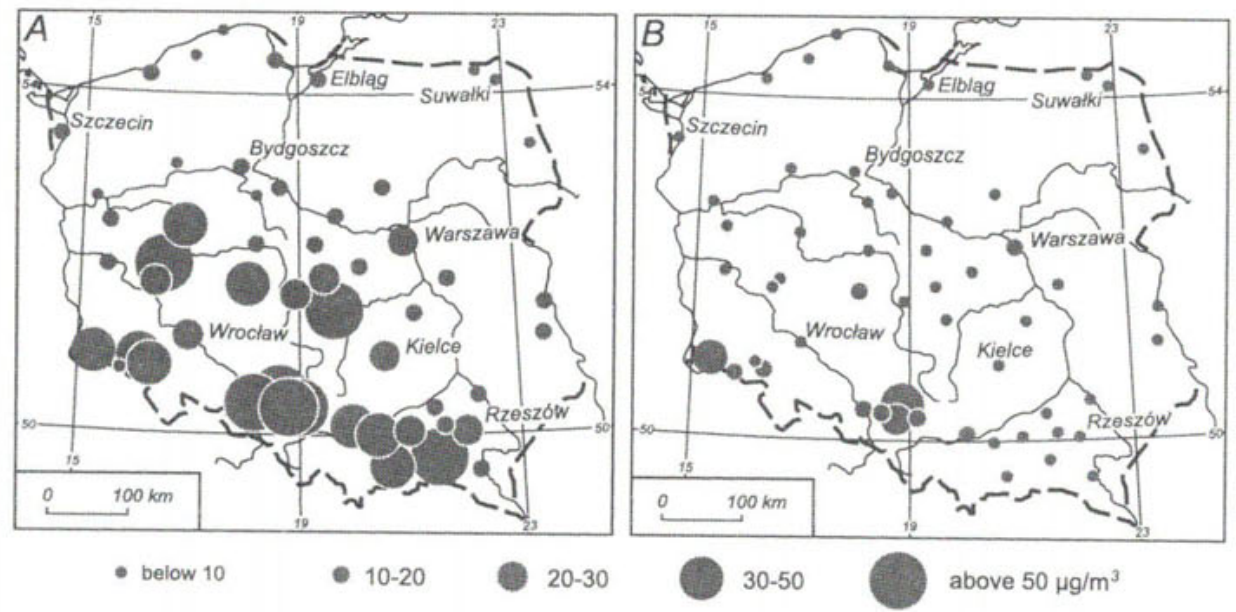

Fig. 2. Mean daily values of sulphur dioxide concentrations in Poland in the cold (A) and warm (B) half-years in the period 1993-97.

changes in emission of sulphur dioxide, which is much higher in winter than during summer, in view of additional sources of this emission (small co-generation plants, local central heating boiler houses, house burners). Annual changes in $\mathrm{SO}_{2}$ concentration result also from the periodical variability of weather conditions (Morawska-Horawska, 1971; Niedźwiedź, Olecki, 1994; Niedźwiedź, Ustrnul, 1989). In the warm half-year an intensive transformation of the sulphur dioxide takes place along with its removal from the atmosphere (amplified photochemical conversion, thicker layer of turbulent mixing, more abundant precipitations).

Table 1.

Mean daily values of sulphur dioxide concentration in seasons of the year and half-years (in $\mu \mathrm{g} / \mathrm{m}^{3}$ )

\begin{tabular}{|l|r|r|r|r|r|r|r|}
\hline \multirow{2}{*}{ Station } & \multirow{2}{*}{$\begin{array}{c}\text { Average } \\
\text { concentration }\end{array}$} & \multicolumn{4}{|c|}{ Seasons of the year } & \multicolumn{2}{c|}{ Half-years } \\
\cline { 3 - 8 } & & Spring & Summer & Autumn & Winter & \multicolumn{1}{c|}{ Cold } & Warm \\
\hline Bytom & 75.0 & 61.8 & 33.4 & 64.0 & 145.2 & 111.6 & 39.1 \\
Kielce & 14.8 & 12.2 & 3.2 & 10.6 & 33.9 & 25.3 & 4.5 \\
Leba & 5.4 & 5.0 & 3.0 & 4.3 & 9.5 & 7.7 & 3.2 \\
Suwałki & 2.9 & 1.9 & 0.7 & 1.8 & 7.2 & 5.0 & 0.8 \\
Warszawa & 20.4 & 19.8 & 9.0 & 22.2 & 30.7 & 16.5 & 11.0 \\
\hline
\end{tabular}

The highest concentration of sulphur dioxide during the whole year is observed in Upper Silesia (Fig. 2). During the cold half-year the average daily concentration of $\mathrm{SO}_{2}$ attains in Bytom $111.6 \mu \mathrm{g} / \mathrm{m}^{3}$, while in the warm half-year $-39.1 \mu \mathrm{g} / \mathrm{m}^{3}$. The least polluted with sulphur dioxide is the air of northern Poland. In this part of the country, even in the cold half-year, the daily concentration of sulphur dioxide is lower than $10 \mu \mathrm{g} / \mathrm{m}^{3}$ (in Suwałki 
— only $5.0 \mu \mathrm{g} / \mathrm{m}^{3}$ ), and in the warm half-year it drops below $5.0 \mu \mathrm{g} / \mathrm{m}^{3}$ (in Suwałki $-0.8 \mu \mathrm{g} / \mathrm{m}^{3}$ ).

\section{SULPHUR DIOXIDE CONCENTRATION FOR VARIOUS DIRECTIONS OF AIR INFLOW}

The dependence of the average daily concentration of sulphur dioxide upon the direction of air inflow is as a rule statistically significant within the area of Poland. The regions, where this dependence is most clearly pronounced are the seacoast and Upper Silesia. The correlation coefficients, measuring the dependence in question, exceed there the values of 0.3-0.4. The relation between the sulphur dioxide concentration and the direction of inflow of air masses is differentiated spatially and it changes during the year. This results first of all from the location of the measurement points with respect to the main emission sources and from the seasonal changes in the speed of transformations of sulphur dioxide. This relation is strong during the whole year in the areas located close to the large emission sources (mainly in Upper Silesia). On the other hand, in the regions far from the important emission sources (like at the seaside) its strength displays a clear annual rhythm. It is very pronounced in the cold half-year, when less of the sulphur dioxide transported with the masses of the air is removed from them or undergoes chemical transformation, and is far weaker in the warm half-year, when conditions for conversion and deposition of this kind of pollution are much more advantageous.

The biggest concentration of $\mathrm{SO}_{2}$ over an important part of Poland takes place when air flows in from the south-eastern and eastern directions. The negative influence of this direction of inflow is especially well seen in the cold half-year (Table 2, Fig. 3).

Table 2.

Mean daily values of sulphur dioxide concentration in the cold half-year for various directions of the air inflow and selected measurement points (in $\mu \mathrm{g} / \mathrm{m}^{3}$ )

\begin{tabular}{|l|c|r|r|r|r|r|r|r|r|r|}
\hline \multirow{2}{*}{ Station } & Average & \multicolumn{10}{|c|}{ Directions of the air inflow } \\
\cline { 3 - 10 } & concentration & \multicolumn{1}{|c|}{$\mathrm{N}$} & \multicolumn{1}{|c|}{$\mathrm{NE}$} & \multicolumn{1}{|c|}{$\mathrm{S}$} & \multicolumn{1}{|c|}{ SE } & \multicolumn{1}{|c|}{ S } & \multicolumn{1}{|c|}{ SW } & W & NW & \multicolumn{1}{c|}{0} \\
\hline Bytom & 111.6 & 74.2 & 93.7 & 144.7 & 164.5 & 123.2 & 99.5 & 78.7 & 68.5 & 118.7 \\
Kielce & 25.3 & 15.1 & 11.5 & 19.7 & 21.8 & 26.3 & 31.0 & 34.1 & 25.7 & 21.9 \\
Łeba & 7.7 & 3.2 & 8.1 & 14.4 & 16.6 & 11.6 & 5.4 & 3.2 & 3.0 & 6.7 \\
Suwałki & 5.0 & 1.6 & 4.0 & 5.2 & 8.6 & 6.2 & 4.3 & 3.1 & 3.5 & 5.0 \\
Warszawa & 29.2 & 19.8 & 29.2 & 31.1 & 45.4 & 41.6 & 25.3 & 20.3 & 17.4 & 28.9 \\
\hline
\end{tabular}

In the days when air flows from the eastern and the south-eastern sectors, Upper Silesia is the area with the worst aerosanitary conditions. Its towns are then within the reach of influence of the large emission sources located in the eastern parts of the same region and in the vicinity of Cracow. 

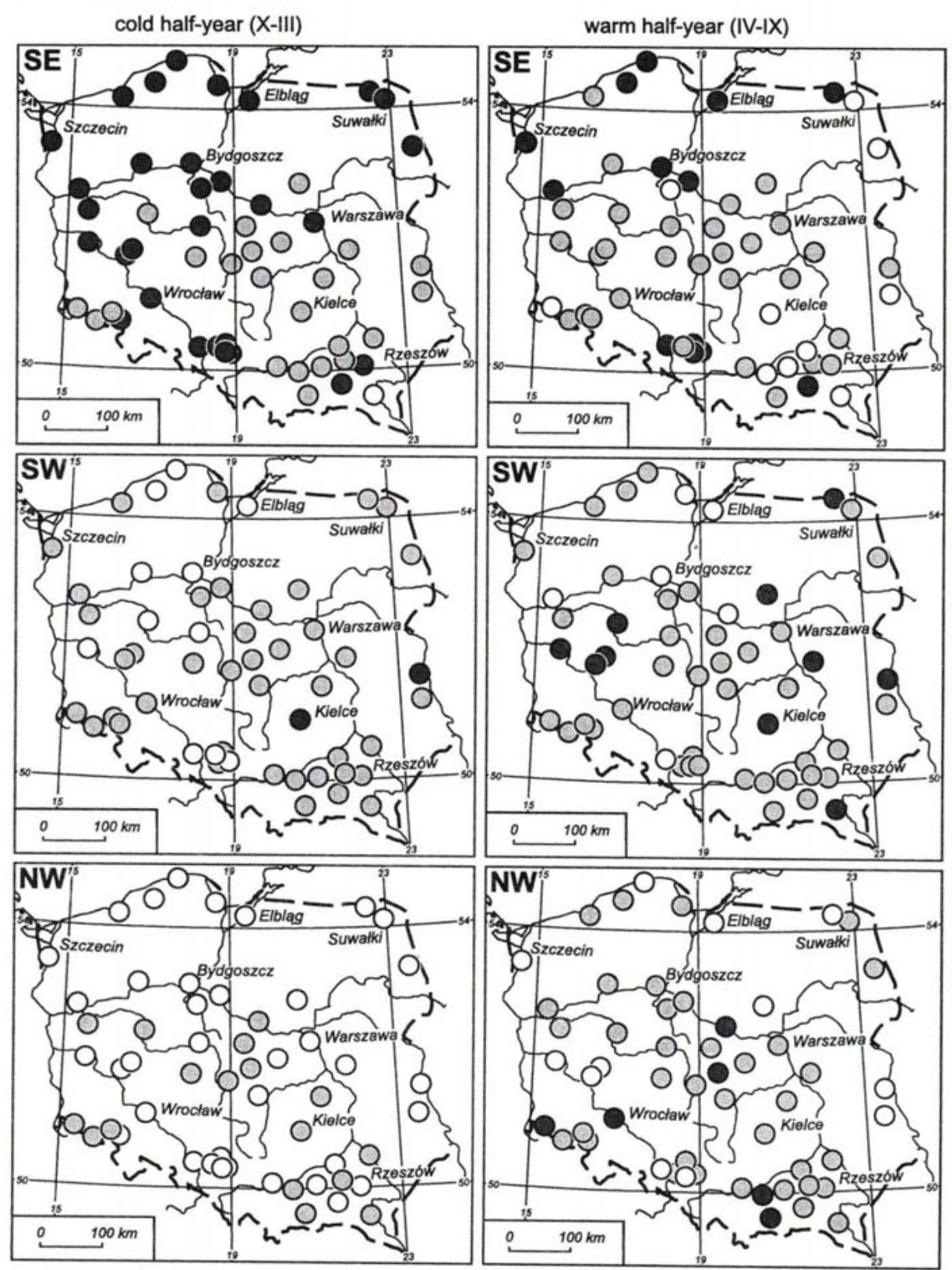

\section{below 80 80-120 above 120}

\section{$\%$ of the average sulphur dioxide} concentration value in a given measurement point in the cold and warm half-years

Fig. 3. Mean daily values of sulphur dioxide concentrations in Poland during south-eastern (SE), south-western (SW), and north-western (NW) wind directions in the periods of cold and warm half-years (1993-1997). 
During such weather conditions concentrations of $\mathrm{SO}_{2}$ often exceeding 150 $\mu \mathrm{g} / \mathrm{m}^{3}$ are noted in Bytom and Zabrze. This situation is especially frequent during the cold half-year.

When air flows in from the south-east, the northern part of Poland, as well, and in particular the seaside, is usually characterised by the relatively high concentrations of $\mathrm{SO}_{2}$. In the cold half-year the $\mathrm{SO}_{2}$ concentrations in the towns of Łeba and Slupsk during such days $\left(16.6\right.$ and $18.5 \mu \mathrm{g} / \mathrm{m}^{3}$, respectively) exceed two times the mean daily concentration in this half-year (7.7 and $8.5 \mu \mathrm{g} / \mathrm{m}^{3}$, respectively). Almost equally disadvantageous is in this half-year the south-eastern direction of inflow in Szczecin (concentration in the days with air inflow from south-east $-20.9 \mu \mathrm{g} / \mathrm{m}^{3}$, average for the half-year $-12.0 \mu \mathrm{g} / \mathrm{m}^{3}$ ). This indicates the industrial areas of southern and central Poland as the main sources of air pollution in this region.

A different situation exists in the southern part of Poland (except for the area of Upper Silesia). The highest concentrations of $\mathrm{SO}_{2}$ are observed here when the masses of air flow in from the south-west and west (Fig. 3). It can be supposed that this is caused by the inflow of sulphur dioxide emitted mainly in Germany and in the Czech Republic. In the south-eastern part of the country there may also be a contribution from the emissions originating in Upper Silesia and the region of Cracow. In the town of Kielce, constituting a typical example of a station from these areas, the $\mathrm{SO}_{2}$ concentration in the days with inflow from the west is in the cold half-year $34.1 \mu \mathrm{g} / \mathrm{m}^{3}$, and in the warm half-year $-7.6 \mu \mathrm{g} / \mathrm{m}^{3}$ (the mean daily values for the whole of these half-year periods are, respectively, 25.3 and $4.5 \mu \mathrm{g} / \mathrm{m}^{3}$ ).

The disadvantageous role of inflow of the air from the south-west and west is more pronounced in the warm half-year. In this season of the year the areas of increased concentration of sulphur dioxide to the north-east of the large-scale power plants come out very clearly. In the cold half-year this image is partly blurred by the presence of many additional dispersed sources of emission.

During the whole year the most advantageous aerosanitary conditions exist in Poland when air flows in from the north-west and north (Fig. 3). Especially in the cold half-year, characterised by a significant pollution of the air with sulphur dioxide, inflow of the air masses from these directions brings an essential decrease of sulphur dioxide concentration. This concentration in many locations falls to less than half of the average. On most of the territory of northern Poland it is below $5 \mu \mathrm{g} / \mathrm{m}^{3}$ (in Suwałki - only $1.6 \mu \mathrm{g} / \mathrm{m}^{3}$ ).

In order to evaluate the risk of appearance in the individual regions of a high concentration of sulphur dioxide, theoretical probability density distributions were determined, approximating the $\mathrm{SO}_{2}$ concentrations for various directions of wind.

On the basis of the cumulative distributions of selected densities the highest values of $\mathrm{SO}_{2}$ concentrations were determined, which can be expected for the individual directions of the air inflow. They are usually very differentiated. As an illustration we present here the results of such an 
analysis concerning Warsaw and Bytom (Fig. 4). In Warsaw (within the western periphery of town) the mean daily concentration of $\mathrm{SO}_{2}$, which will be exceeded with probability $2 \%$, equals for the inflow of the air from the north-west $-44 \mu \mathrm{g} / \mathrm{m}^{3}$, and for the inflow from the south $-117 \mu \mathrm{g} / \mathrm{m}^{3}$. The values of the concentration in Bytom are: for the inflow of the air from the north-west $-74 \mu \mathrm{g} / \mathrm{m}^{3}$, and for the inflow from south-east $-288 \mu \mathrm{g} / \mathrm{m}^{3}$.
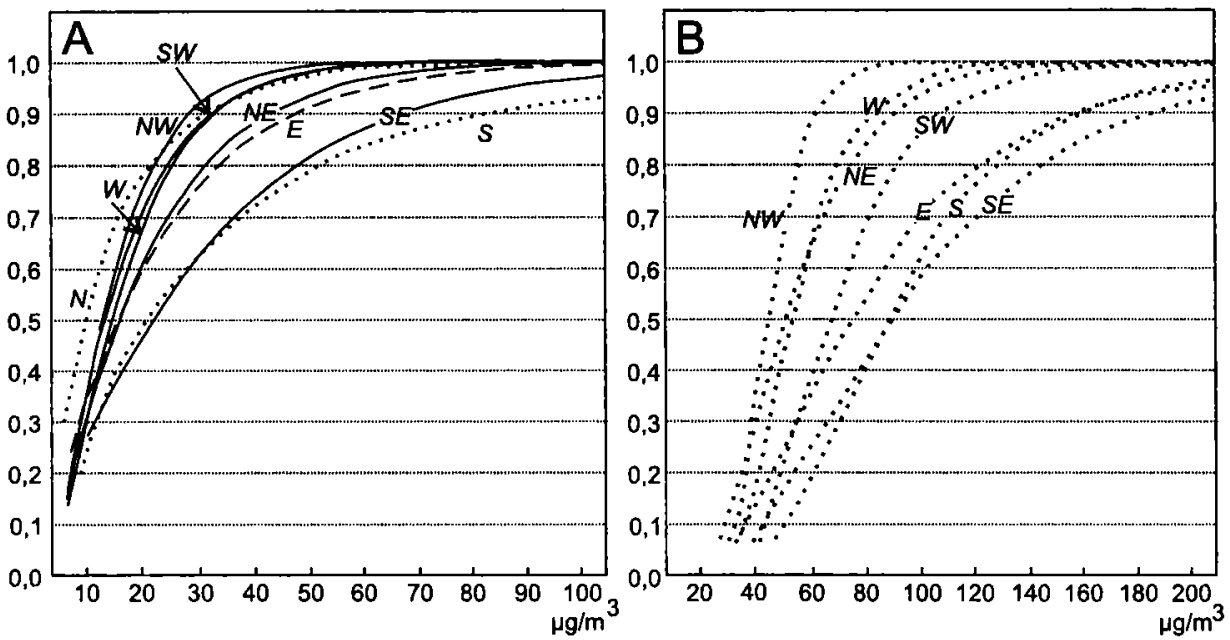

Fig. 4. Curves of the cumulative distribution functions of the following probability distributions: log-normal (dotted line), gamma (continuous line), and exponential (broken line), of the mean daily sulphur dioxide concentrations for different directions of the air inflow in Warsaw (A) and Bytom (B).

The theoretical cumulative distributions of the particular density functions make it also possible to determine the probabilities of exceeding the mean daily values which are legal admissible limits: $200 \mu \mathrm{g} / \mathrm{m}^{3}$ within the protected areas $\left(150 \mu \mathrm{g} / \mathrm{m}^{3}\right.$ since 1999$)$ and $75 \mu \mathrm{g} / \mathrm{m}^{3}$ within the specially protected areas. Probabilities of exceeding these threshold values were determined for various directions of the air inflow and for all these stations, where systematic violation of the norms had been observed (results concerning selected stations are shown in Table 3). In all the locations considered the risk of appearance of the so high $\mathrm{SO}_{2}$ concentration takes place for only

Table 3.

Probabilities that the main daily sulphur dioxide concentration will exceed $200 \mu \mathrm{g} / \mathrm{m}^{3}$ for various directions of theair inflow at selected stations.

\begin{tabular}{|l|c|c|c|c|c|c|c|c|}
\hline \multirow{2}{*}{ Station } & \multicolumn{10}{|c|}{ Directions of air inflow } \\
\cline { 2 - 9 } & $\mathrm{N}$ & $\mathrm{NE}$ & $\mathrm{E}$ & $\mathrm{SE}$ & $\mathrm{S}$ & $\mathrm{SW}$ & $\mathrm{W}$ & $\mathrm{NW}$ \\
\hline Bytom & $\mathrm{x}$ & 0.1 & 4.2 & 7.5 & 3.1 & 0.1 & 0.0 & 0.0 \\
Katowice & $\mathrm{x}$ & 0.2 & 2.8 & 2.2 & 0.3 & 0.0 & 0.0 & $\mathrm{x}$ \\
Warszawa & 0.0 & 0.0 & 0.0 & 0.1 & 2.0 & 0.0 & 0.0 & 0.0 \\
\hline
\end{tabular}


some directions of the air inflow. Thus, for instance, in Bytom, the probability of exceeding the limit of $200 \mu \mathrm{g} / \mathrm{m}^{3}$ when the air flows in from the south-east is as high as 7.5\%, while for the inflow of the air masses from the west or north-west there is no threat of appearance of the so high concentration of $\mathrm{SO}_{2}$. In Warsaw, the probability of appearance of this concentration of sulphur dioxide arises only for the air inflow from the directions ranging between southern $(2.0 \%)$ and south-eastern $(0.1 \%)$.

\section{DAY-TO-DAY VARIABILITY OF SULPHUR DIOXIDE CONCENTRATIONS FOR DIFFERENT AIR INFLOW DIRECTIONS}

The area of Poland is very differentiated with respect to the day-to-day variability of sulphur dioxide concentrations. In the northern part of the country very small day-to-day concentration changes (of the order of $\pm 1-2 \mu \mathrm{g} / \mathrm{m}^{3}$ ) dominate, and the cases of changes exceeding $20 \mu \mathrm{g} / \mathrm{m}^{3}$ are sporadic. In southern Poland large variations of $\mathrm{SO}_{2}$ concentrations $\left( \pm 20-50 \mu \mathrm{g} / \mathrm{m}^{3}\right)$ are frequent, and in the extreme cases the increases and decreases exceeding $100 \mu \mathrm{g} / \mathrm{m}^{3}$ may take place.

The jump-like increases of sulphur dioxide concentrations appear over the majority of the area of Poland especially frequently in the days with the air inflow from the south-east and east (both on the first such day, and in the consecutive days of the inflow of air masses from these directions). In the south-western and south-eastern parts of the country the frequency of high increases of the $\mathrm{SO}_{2}$ concentration from day to day gets more frequent when air masses flow in from the south-western and western directions. The situation when no well-marked flows occur is also conducive to the significant sulphur dioxide concentration increases.

The particular directions of the air transport are much less differentiated in terms of frequency of important decreases of $\mathrm{SO}_{2}$ concentrations from day to day.

The smallest day-to-day changes of sulphur dioxide concentrations take place when the air flows in from the northern directions. The inflow of air masses from this sector leads also to a significant homogenisation of the $\mathrm{SO}_{2}$ concentration changes over the whole area of the country. On the other hand, inflow of the air from the south and south-east, as well as lack of any significant movement of the air masses, lead to the most pronounced differentiation among the particular regions.

\section{SPATIAL DISTRIBUTION OF DEPENDENCE OF AIR POLLUTION WITH SULPHUR DIOXIDE ON THE AIR INFLOW DIRECTIONS}

Existence of a distinct spatial differentiation of the relation between sulphur dioxide concentration and the direction of the air inflow in Poland allowed for the undertaking of an attempt of determining regions featuring 
similar patterns of the dependence described. Cluster analysis was used for this purpose.

The situation with respect to air pollution caused by sulphur dioxide in selected stations was described by calculating: averages, small $(0.50$ percentile) and very high ( 0.95 percentile) concentrations, average day-to-day concentration increases and decreases, very big day-to-day concentration decreases ( 0.05 percentile) and very high increases ( 0.95 percentile) for definite directions of the air inflow. On the basis of the thus elaborated information matrix directions were identified with the Ward's method for which the aerosanitary state in a given measurement point is similar. Joint consideration of results obtained from various measurement points allowed to demonstrate a distinct differentiation of the territory of Poland in terms of dependence of sulphur dioxide concentration in the air upon the direction of air inflow.
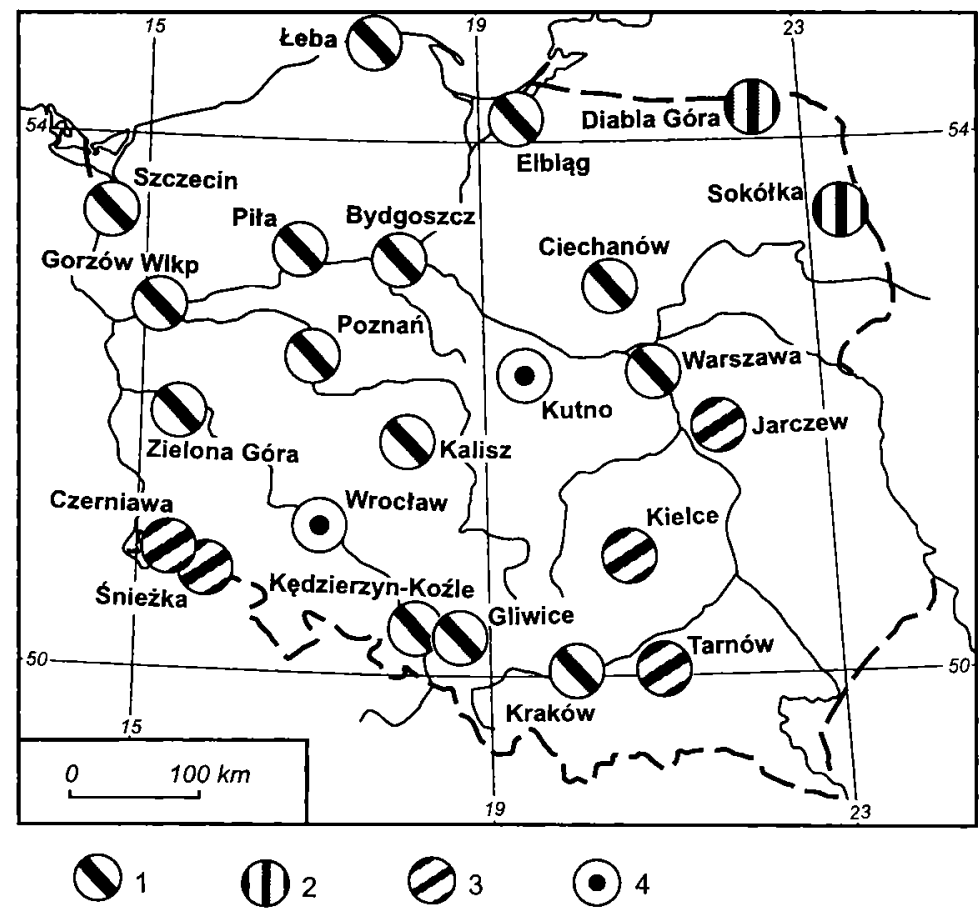

Fig. 5. Directions of the air inflow for which pollution of the air with the sulphur dioxide in Poland displays the biggest differentiation. Stations, at which the largest dissimilarity characterises the sectors: 1 - north-western (advantageous) and south-eastern (disadvantageous), 2 northern (advantageous) and southern (disadvantageous), 3 - north-eastern (advantageous) and south-western (disadvantageous), 4 - stations without a clear setting of similatities between the individual directions of the air inflow.

Generally, well defined areas can be distinguished in Poland, for which the influence of respective sectors from where the air flows in turns out to 
be of the opposite kind (leading to opposite consequences in terms of pollution). These pairs of sectors are, as shown in Fig. 5:

- The north-western (as advantageous) and the south-eastern (as disadvantageous),

- The northern (as advantageous) and the southern (as disadvantageous),

- The north-eastern (as advantageous) and the south-western (as disadvantageous).

The area corresponding to the first of these pairs encompasses the northwestern, the central, and partly the southern Poland. The disadvantageous aerosanitary conditions which exist in this area during the inflow of the air masses from the south-east (high sulphur dioxide concentration and its frequent increases) contrast sharply with the conditions typical for days with the air inflow from the north-west (low concentration and its small changes). The difference indicated is most clear at the seacoast, where these two directions of the air inflow bring in either the polluted air from above the land, or the clean air masses from above the sea. The difference between the pollution conditions corresponding to the air inflow from these two sectors diminishes as we move inland, due to greater dispersion of the sources of $\mathrm{SO}_{2}$ emissions.

The eastern and the southern parts of the country display with respect to the feature considered a distinct difference. Thus, in the north-east of the country the pair of the opposite sectors in terms of pollution conditions are the northern and the southern sectors. In the south-western Poland, as well as in the area located to the east and to the north-east of Upper Silesia and Cracow these are the north-eastern and the south-western sectors.

\section{REFERENCES}

M oraw ska-H or a w ska M., 1971, Wplyw warunków atmosferycznych na rozchodzenie się dwutlenku siarki w Krakowie i okolicy [The influence of meteorological conditions on dispersion of sulphur dioxide in Cracow and its vicinity], Folia Geographica, Ser. Geographica-Physica, 5, Warszawa.

Niedźwiedź T., Olecki Z., 1994, Wpływ sytuacji synoptycznych na zanieczyszczenie powietrza w Krakowie [The Influence of synoptic situations on air pollution in Cracow], Prace Geograficzne, 96, Kraków.

Niedźwiedź T., Ustrnul Z., 1989, Wpływ sytuacji synoptycznej na występowanie nad Górnośląskim Okręgiem Przemysłowym typów pogody sprzyjających koncentracji lub rozpraszaniu zanieczyszczen powietrza [The Influence of synoptic situation on the occurrence of weather types favouring cumulation or dispersion of air pollution over Upper Silesia], Wiadomości Instytutu Meteorologii $i$ Gospodarki Wodnej, XII (XXXIII), 1-2, Warszawa.

OECD Environmental Data Compendium, 1999, Paris. 